\title{
Enteric parasitic infection among HIV-infected patients visiting Tribhuvan University Teaching Hospital, Nepal
}

\author{
Ananda Ghimire', Shiva Bhandari², Sarmila Tandukar ${ }^{3}$, Jyoti Amatya ${ }^{4}$, Dinesh Bhandari ${ }^{3 *}$ \\ and Jeevan Bahadur Sherchand ${ }^{3}$
}

\begin{abstract}
Background: Enteric parasitic infection among human immunodeficiency virus (HIV) patients has been a significant health problem in developing countries like Nepal. This study was undertaken to access the burden of enteric parasites among HIV patients and its association with their immune status.

Methods: A cross-sectional study, involving 112 HIV sero-positive patients was conducted in Tribhuvan University Teaching Hospital, Public Health Research Laboratory, Kathmandu, Nepal from July 2011 to June 2012. The fecal samples were processed by direct-smear technique, in both normal saline solution and $1 \%$ iodine solution as well as modified acid fast staining (Kinyoun's method) after formalin ether concentration and Sheather's sucrose flotation for the identification of enteric parasites.

Results: Infection with one or more parasite was seen in $33.9 \%(n=38)$ of the cases enrolled in the study, with the parasite prevalence rate of $41.1 \%(n=46)$. Literacy $(O R=1.9,95 \% \mathrm{Cl} 0.9-4.3)$ and CD4 T-cell count $<200(\mathrm{OR}=2.5$, $95 \% \mathrm{Cl} 1.1-5.7)$ were found to be associated with enteric parasite infection. Similarly, CD4 T-cell count $<200$ was found to be associated with opportunistic parasitic infection $(\mathrm{OR}=3.2,95 \% \mathrm{Cl}$ 1.2-7.8). Among opportunistic parasites, Giardia duodenalis was the most common $(28.3 \%, n=13)$ one. Multi-parasitism was observed in six patients (15.8\%).

Conclusion: Enteric parasitic infections are common in HIV-infected people. The poor immune status as indicated by low CD4 T-cell count may account for higher risk of both opportunistic and non-opportunistic enteric parasitic infection.
\end{abstract}

Keywords: CD4 T-cell, Diarrhea, Enteric parasites, HIV, Multi-parasitism

\section{Background}

Globally, HIV/AIDS has been a major health problem and the scourge of HIV/AIDS is most unfortunate for resource poor countries like Nepal. In Nepal, more than 25,000 people are living with HIV and only $39 \%$ of them are in reach of life-saving highly active antiretroviral therapy (HAART) [1]. The severity is increased due to opportunistic infections. Enteric parasites are one of

\footnotetext{
*Correspondence: me.dinesh43@gmail.com

${ }^{3}$ Public Health Research Laboratory, Institute of Medicine, Tribhuvan

University Teaching Hospital, Maharajgunj, Kathmandu, Nepal

Full list of author information is available at the end of the article
}

the most common infections among HIV/AIDS patients [2-4]. Studies report that several factors including lower CD4 T-cell count, diarrhea, living in a rural area and poor nutrition have been associated with the higher prevalence of enteric parasitic infection in HIV-infected individuals [5-8].

In addition, the occurrence of multi-parasitism has been reported and can lead to negative health outcomes $[9,10]$ and the condition is worsened in socially and economically marginalized communities [11]. Nepal is among the countries with overlapping high rate of HIV and parasitic infections. Therefore, this study was conducted to detect enteric parasitic infections among 
HIV-seropositive patients visiting Tribhuvan University Teaching Hospital (TUTH) and association with the immune status of the patients.

\section{Methods}

\section{Study setting and study population}

A cross-sectional type study was carried among the HIV patients attending the TUTH for their regular HAART therapy and HIV counseling from July 2011 to June 2012. Tribhuvan University Teaching Hospital with a total of 444 beds is the largest tertiary care hospital in Nepal that deals with all type of diseases and conditions requiring medical attention.

A total of 112 HIV patients were included in the study and stool specimen was collected from each of them. Patients who were not infected with HIV were excluded from the study.

\section{Specimen collection, transportation and processing}

Fresh stool specimens were collected in labeled, leak proof, clean sterile plastic containers according to the World Health Organization (WHO) standard procedure [12], and transported maintaining cold chain, as quickly as possible to Public Health Research Laboratory, Institute of Medicine for laboratory investigation. Stool specimens were examined microscopically for ova, cysts, oocyst, or parasites, using different techniques. The stool samples were fixed in $10 \%$ formalin, concentrated using formyl/ethyl acetate [13] and Sheather's sucrose floatation technique and stained in modified acid-fast staining technique [14]. The direct observation was made in saline $(0.85 \% \mathrm{NaCl}$ solution) and Modified Ziehl Neelsen staining was used for smears of concentrated specimens to examine Cyclospora cayetanensis, Cryptosporidium spp. and Cystoisospora belli (CCC) $[12,15]$.

\section{CD4 T-cell count}

The patient's recent CD4 T-cell count was noted from the record they possessed.

\section{Statistical analysis}

All the results were recorded in the worksheet, entered and analyzed using Statistical Package for the Social Sciences (SPSS) (SPSS Inc., Chicago, version 16). Descriptive statistics were carried out. Frequencies were calculated for categorical variables. Proportions were compared using Fisher's exact test. Odds ratio (OR) and $95 \%$ confidence intervals (CI) were calculated using a bivariate logistic regression. Tests were considered significant at $P$ value $<0.05$.

\section{Ethical approval}

The approval for the study was obtained from the Research Department, TUTH. All the participants were explained about the purpose and their participation was voluntary in this study. Informed verbal and written consent was taken from each participant. Moreover, all personal information of the participants was kept confidential. Participants diagnosed as being infected with intestinal parasites were referred appropriately for treatment.

\section{Operational definitions}

A participant was defined as intestinal parasite positive if the stool specimen was positive for at least one of either a pathogenic protozoa or a helminths in microscopic examination. Similarly, a participant was categorized as intestinal parasite negative if the stool specimen on microscopic examination was not positive for pathogenic intestinal parasites. Diarrhea was defined as three or more runny or liquid stool passed within 24 h [16]. Multi-parasitism was defined as the concurrent infestation of a single host individual with two or more parasite species [17].

\section{Results}

A total of 112 stool samples were collected from HIV patients undergoing HAART therapy from TUTH. Out of the samples processed, more than a third patients $(33.9 \%)$ were identified with parasites while the prevalence of parasites was $41.1 \%(n=46)$. The chances of having parasitic infections in females was 1.4 times more than in males. Similarly, illiterate patients were about two times more likely to be infected with parasites than the literate ones (Table 1).

\section{Immune status of cases and enteric parasites prevalence}

The chances of parasitic infections in persons with CD4 T-cell count $<200$ was 2.5 times higher than those with CD4 T-cell count $\geq 200$. Similarly, the chances of getting diarrhea in patients with CD4 T-cell count of $<200$ was more than two times higher (Table 2).

Table 1 Factors associated with parasitic infection in HIV patients

\begin{tabular}{|c|c|c|c|}
\hline Variables & $\begin{array}{l}\text { Parasite } \\
\text { positive (\%) }\end{array}$ & $\begin{array}{l}\text { Odds ratio } \\
(95 \% \mathrm{Cl})\end{array}$ & $P$ value \\
\hline $\begin{array}{l}\text { Number of participants } \\
\qquad(\mathrm{n}=112)\end{array}$ & $38(33.9)$ & - & \\
\hline $\begin{array}{l}\text { Mean age }( \pm S D) \\
\quad(15-64) \text { in years }\end{array}$ & $38.0 \pm 10.1$ & - & \\
\hline \multicolumn{4}{|l|}{ Gender } \\
\hline Male $(n=65)$ & $20(30.8)$ & 1 & \\
\hline Female $(n=47)$ & $18(38.3)$ & $1.4(0.6-3.1)$ & 0.41 \\
\hline \multicolumn{4}{|l|}{ Literacy } \\
\hline Literate $(n=50)$ & $13(26.0)$ & 1 & \\
\hline Illiterate $(n=62)$ & $25(40.3)$ & $1.9(0.9-4.3)$ & 0.05 \\
\hline
\end{tabular}


Table 2 Association of parasitic infection and diarrhea with CD4 T-cell count

\begin{tabular}{|c|c|c|c|c|c|}
\hline CD4 T-cell/ $\mu \mathrm{L}$ & Total (\%) & Parasites detected (\%) & OR $(95 \% \mathrm{CI})$ & Diarrhea (\%) & OR $(95 \% \mathrm{Cl})$ \\
\hline$<200$ & $30(26.8)$ & $18(60.0)$ & $2.5(1.1-5.7)^{*}$ & $4(13.3)$ & $2.2(0.4-9.9)$ \\
\hline$\geq 200$ & $82(73.2)$ & $28(34.1)$ & 1 & $3(3.7)$ & 1 \\
\hline Total (\%) & $112(100.0)$ & $46(41.1)$ & - & $7(6.3)$ & - \\
\hline
\end{tabular}

* Significant difference at $\mathrm{P}<0.05$

The most frequently identified parasite was Giardia duodenalis (syn. Giardia intestinalis and Giardia lamblia) $(28.3 \%, \mathrm{n}=13)$. Altogether, $69.5 \%(\mathrm{n}=32)$ opportunistic parasites: G. duodenalis, CCC and Blastocystis hominis were identified. The opportunistic parasites were dominantly identified ( $46.6 \%, \mathrm{n}=14)$ in patients having CD4 T-cell count $<200$. Similarly, the chances of opportunistic infection in patients having CD4 T-cell count $<200$ was about 3.5 times higher $(\mathrm{OR}=3.4$, $95 \%$ CI $1.1-$ 10.1) than in other patients. Non-opportunistic parasite, Entamoeba histolytica was identified in higher number in both patients with CD4 T-cell count <200 (13.3\%, n = 4) and CD4 T-cell count $\geq 200(8.5 \%, \mathrm{n}=7)$ (Table 3$)$.

\section{Multiple parasitisms in HIV patients}

Out of 38 patients in whom parasites were detected, six patients (15.8\%) showed multi-parasitism. Two patients (5.3\%) were simultaneously infected with three parasites: E. histolytica, C. cayetanensis, and Cryptosporidium spp. (Table 4).

\section{Discussion}

In the present study, more than a third of the HIV patients undergoing HAART therapy from TUTH were found to have parasitic infections. In different studies done in Nepal, the prevalence of enteric parasites in HIV

Table 3 Distribution of parasitic infection in HIV patients

\begin{tabular}{llll}
\hline $\begin{array}{l}\text { Parasites } \\
(n=46)\end{array}$ & $\begin{array}{l}\text { Number } \\
(\%)\end{array}$ & CD4 T-cell count & OR $(95 \% \mathrm{Cl})$ \\
\cline { 2 - 3 } & & $<200$ & $\geq 200$ \\
& & $(\mathrm{n}=30)(\%)(\mathrm{n}=82)(\%)$
\end{tabular}

\begin{tabular}{lrrrr}
\hline Non-opportunistic & & & & \\
E. histolytica & $11(23.9)$ & $4(13.3)$ & $7(8.5)$ & $1.2(0.4-4.4)$ \\
E. coli & $3(6.5)$ & $0(0.0)$ & $3(3.7)$ & \\
$\begin{array}{l}\text { Opportunistic } \\
\text { G. duodenalis }\end{array}$ & $13(28.3)$ & $5(16.7)$ & $8(9.8)$ & $3.2(1.2-7.8)^{*}$ \\
$\begin{array}{l}\text { C. cayetanensis } \\
\text { Cryptosporidium } \\
\text { spp. }\end{array}$ & $8(17.4)$ & $3(10.0)$ & $5(6.1)$ & \\
$\begin{array}{l}\text { C. belli } \\
\text { B. hominis }\end{array}$ & $1(2.2)$ & $1(3.3)$ & $0(0.0)$ & \\
\hline
\end{tabular}

* Significant difference at $\mathrm{P}<0.05$
Table 4 Presence of multi-parasitism in HIV patients

\begin{tabular}{ll}
\hline Parasites co-infection & $\begin{array}{l}\text { Number of patients } \\
(\mathbf{n}=\mathbf{3 8}) \mathbf{( \% )}\end{array}$ \\
\hline $\begin{array}{l}\text { E. histolytica + C. cayetanensis } \\
\quad+\text { Cryptosporidium spp. }\end{array}$ & $2(5.3)$ \\
E. histolytica + Cryptosporidium spp. & $1(2.6)$ \\
E. histolytica + C. cayetanensis & $1(2.6)$ \\
E. histolytica + E. coli & $1(2.6)$ \\
C. cayetanensis + Cryptosporidium spp. & $1(2.6)$ \\
\hline
\end{tabular}

patients ranged from $22.4 \%$ to more than $35.0 \%$ under different settings $[7,18,19]$. The present study showed that chance of infection with parasites in illiterates was nearly double as compared to the literates. In concordance to our finding, a similar study from India reported lower percentage of parasitic infection owing to a better educational status [20]. Our study also suggested that females had higher chance of parasitic infection than males and this finding is supported by the study done in India [20]. On the contrary, other studies from Nepal [18] and Nigeria [21] showed that more males had parasitic infections than females. The sexual division of labor and the sexual division of responsibility together with local ecological, environmental, economic and cultural factors influence exposure to infection and risk of disease [22]. In developing countries like Nepal, a high disparity exists between male and female in terms of education opportunity, nutritional status and access to medical facilities; the gross effect of which can be accounted for a higher chance of parasitic infection in females than male in current study. However, the role of gender and literacy in parasitic infections is always contradictory and further rigorous research is required.

This study showed that chance of parasitic infections in persons with CD4 T-cell count $<200$ was 2.5 times higher than those with CD4 T-cell count $\geq 200$. In studies done in Nepal, more than three-fifth [18] to four-fifth [7] of the HIV patients with CD4 T-cell count $<200$ had parasitic infections. Other studies have depicted the importance of immunity in parasitic infections, [23, 24] which supports our study. The present study showed that there was more than two times higher chances of getting diarrhea 
in patients with CD4 T-cell count $<200$. This finding is supported by several studies where higher prevalence of diarrhea was observed in lower CD4 T-cell counts patients [7, 8, 25-27]. The association between diarrhea, lower CD4 T-cell count and presence of intestinal parasites is little understood and needs to be further studied.

In the present study, G. duodenalis was the most common parasite $(28.3 \%, \mathrm{n}=13)$. In different studies done in Nepal, 6.7-35.0 \% of G. duodenalis were identified in HIV patients [18, 28, 29]. The non-opportunistic parasites identified were protozoan parasites: $E$. histolytica and Entamoeba coli, and no helminthes were identified. However, other studies showed the prevalence of helminthes among HIV patients [7, 21,30].

In our study, about 7 out of 10 parasites identified were opportunistic parasites: G. duodenalis, CCC and B. hominis. These parasites have been considered opportunistic by other authors as well [31-33]. Giardia duodenalis, was the most common $(28.3 \%, \mathrm{n}=13)$ opportunistic parasite identified, which was higher as compared to other studies done in Nepal $[7,18]$. In other parts of the world, the prevalence ranged from $9.3 \%$ in India [34] to $43.6 \%$ in Ethiopia [32]. Generally, the variation in the prevalence of cryptosporidial infections could be related to the processing of single stool specimen, which might underestimate the prevalence of cryptosporidial infection [35]. Moreover, oocyst excretion is usually variable $[35,36]$. The prevalence of C. cayetanensis was $17.4 \%(\mathrm{n}=8)$, which is slightly higher than in other studies done in Nepal $[7,18]$. Cystoisospora belli and B. hominis were less frequently identified parasites in the current study. However, the prevalence of B. hominis varied from 1.2 to $6.2 \%$ in studies done in Nepal [7, 18, 28].

The opportunistic parasites were dominantly identified $(46.7 \%, \mathrm{n}=14)$ in patients having CD4 T-cell count $<200$. However, a study done in Nepal showed lower prevalence of opportunistic parasites (27.4\%) [7]. Low CD4 T-cell count is significantly associated with opportunistic parasitic infections as shown by different studies $[7,8,37,38]$. It has also been established that T lymphocytes and the cytokines they produce play a crucial role in determining the outcome of parasitic infection [39].

We observed multi-parasitism in six patients (15.8\%) in our study. Studies have shown there existed multi-parasitism in Nepal [28] and other parts of the world [33, 40, 41]. A simultaneous infection with different parasites can be a chance, that is, each infection is independent from other infections. In addition, high numbers of parasites and the presence of different species in certain individuals can be due to genetic and immunological predisposition to parasite infections $[42,43]$.

This study was not without limitations. Firstly, the patients might have treated themselves with anti-parasitic treatments, some of which such as metronidazole, mebendazole and albendazole are easily available without prescription in Nepal. Secondly, single stool sample of the patients was analyzed, which might lead to missed parasitological diagnoses. Thirdly, HIV negative control groups were not included in this study, which might be helpful in comparing different variables among the two groups.

\section{Conclusion}

Enteric parasitic infections still remain significant health problem in Nepal especially among HIV-infected persons with and without diarrhea. $69.5 \%$ of parasites identified were opportunistic in nature among which the majority of the opportunistic parasitic infections were observed in the patients with CD4 T-cell count $<200$. The current finding also highlights the importance of detection of multi-parasitism among HIV-seropositive patients. It is equally important that the concerned organizations help to manage and improve quality of life of HIV-infected individuals and to avoid morbidity and mortality due to opportunistic pathogens.

\section{Authors' contributions}

AG: Research design, sample collection, laboratory work, result analysis and manuscript preparation; SB and DB: Research design, result analysis and manuscript preparation; ST: Sample collection and laboratory work; JA and JBS; Overall supervision of the research project. All the authors read and approved the final manuscript.

\section{Author details}

'Blood Transfusion Service, Department of Pathology, Tribhuvan University Teaching Hospital, Maharajgunj, Kathmandu, Nepal. ${ }^{2}$ Nutrition Innovation Lab, Nepal/Johns Hopkins University, Patan Dhoka, Lalitpur, Kathmandu, Nepal. ${ }^{3}$ Public Health Research Laboratory, Institute of Medicine, Tribhuvan University Teaching Hospital, Maharajgunj, Kathmandu, Nepal. ${ }^{4}$ Department of Microbiology, Trichandra Multiple College, Ghantaghar, Kathmandu, Nepal.

\section{Acknowledgements}

The authors would like to acknowledge the support and facility provided by the staffs of Public Health Research Laboratory, TUTH and all the participants without whom this research would not have been possible.

\section{Competing interests}

The authors declare that they have no competing interests.

Received: 8 October 2015 Accepted: 23 March 2016

Published online: 06 April 2016

\section{References}

1. National Centre for AIDS and STD Control (NCASC). Factsheet 2: reported HIV cases as of Asar 2071 (2014). Kathmandu: Government of Nepal, NCASC; 2014. Accessed date: 15 Jul 2014http://www.ncasc.gov.np/ uploaded/facts_n_figure/2014_Factsheet_2_Reported_HIV_Cases_2014. pdf.

2. Patel SD, Kinariwala DM, Javadekar TB. Clinico-microbiological study of opportunistic infection in HIV seropositive patients. Indian J Sex Transm Dis. 2011;32(2):90-3.

3. Jha AK, Uppal B, Chadha S, Bhalla P, Ghosh R, Aggarwal P, et al. Clinical and microbiological profile of HIV/AIDS cases with diarrhea in North India. J Pathog. 2012;2012:7. 
4. Takalkar AA, Saiprasad GS, Prasad VG, Madhekar NS. Study of opportunistic infections in HIV seropositive patients admitted to community Care centre (CCC), KIMS Narketpally. Biomed Res. 2012;23(1):139-42.

5. Tarimo DS, Killewo JZ, Minjas JN, Msamanga Gl. Prevalence of intestinal parasites in adult patients with enteropathic AIDS in north-eastern Tanzania. East Afr Med J. 1996;73(6):397-9.

6. Modjarrad K, Zulu I, Redden DT, Njobvu L, Freedman DO, Vermund SH. Prevalence and predictors of intestinal helminth infections among human immunodeficiency virus type 1-infected adults in an urban African setting. Am J Trop Med Hyg. 2005;73(4):777-82.

7. Tiwari BR, Ghimire P, Malla S, Sharma B, Karki S. Intestinal parasitic infection among the HIV-infected patients in Nepal. J Infect Dev Ctries. 2013;7(7):550-5.

8. Assefa S, Erko B, Medhin G, Assefa Z, Shimelis T. Intestinal parasitic infections in relation to HIV/AIDS status, diarrhea and CD4 T-cell count. BMC Infect Dis. 2009;9:155.

9. Ezeamama AE, Friedman JF, Olveda RM, Acosta LP, Kurtis JD, Mor V, et al. Functional significance of low-intensity polyparasite helminth infections in anemia. J Infect Dis. 2005;192(12):2160-70.

10. Pullan $\mathrm{R}$, Brooker $\mathrm{S}$. The health impact of polyparasitism in humans: are we under-estimating the burden of parasitic diseases? Parasitology. 2008;135(7):783-94.

11. Schratz A, Pineda MF, Reforma LG, Fox NM, Le Anh T, Tommaso CavalliSforza L, et al. Neglected diseases and ethnic minorities in the Western Pacific Region exploring the links. Adv Parasitol. 2010;72:79-107.

12. World Health Organization. Basic laboratory methods in medical parasitology. Geneva: World Health Organization; 1991.

13. Ridley DS, Hawgood BC. The value of formol-ether concentration of faecal cysts and ova. J Clin Pathol. 1956;9(1):74-6.

14. Henriksen SA, Pohlenz JF. Staining of cryptosporidia by a modified ZiehlNeelsen technique. Acta Vet Scand. 1981;22(3-4):594-6.

15. Centers for disease control and prevention (CDC). DPDx-Laboratory identification of parasitic diseases of public health concern. Atlanta: CDC; 2105. http://www.cdc.gov/dpdx/.

16. Gidudu J, Sack DA, Pina M, Hudson MJ, Kohl KS, Bishop P, et al. Diarrhea: case definition and guidelines for collection, analysis, and presentation of immunization safety data. Vaccine. 2011;29(5):1053-71.

17. Steinmann P, Utzinger J, Du ZW, Zhou XN. Multiparasitism a neglected reality on global, regional and local scale. Adv Parasitol. 2010;73:21-50.

18. Sherchan JB, Ohara H, Sakurada S, Basnet A, Tandukar S, Sherchand JB, et al. Enteric opportunistic parasitic infections among HIV seropositive patients in Kathmandu, Nepal. Kathmandu Univ Med J (KUMJ). 2012;10(38):14-7.

19. Adhikari NA, Rai SK, Singh A, Dahal S, Ghimire G. Intestinal parasitic infections among HIV seropositive and high risk group subjects for HIV infection in Nepal. Nepal Med Coll J. 2006;8(3):166-70.

20. Dhanabal J, Selvadoss PP, Muthuswamy K. Comparative study of the prevalence of intestinal parasites in low socioeconomic areas from South Chennai, India. J Parasitol Res. 2014;2014:630968.

21. Akinbo FO, Okaka CE, Omoregie R. Prevalence of intestinal parasitic infections among HIV patients in Benin City, Nigeria. Libyan J Med. 2010;5:5506.

22. Okwa OO. Tropical parasitic diseases and women. Ann Afr Med. 2007;6:157-63.

23. MacDonald AS, Araujo MI, Pearce EJ. Immunology of parasitic helminth infections. Infect Immun. 2002;70(2):427-33.

24. Girgis NM, Gundra UM. Loke Pn. Immune regulation during helminth infections. PLoS Pathog. 2013;9(4):e1003250.

25. Tuli L, Gulati AK, Sundar S, Mohapatra TM. Correlation between CD4 counts of HIV patients and enteric protozoan in different seasons-an experience of a tertiary care hospital in Varanasi (India). BMC Gastroenterol. 2008;8:36.

26. Lehman LG, Kangam L, Mbenoun ML, Zemo Nguepi E, Essomba N, Tonga C, et al. Intestinal parasitic and candida infection associated with HIV infection in Cameroon. J Infect Dev Ctries. 2013;7(2):137-43.

27. Attili SV, Gulati AK, Singh VP, Varma DV, Rai M, Sundar S. Diarrhea, CD4 counts and enteric infections in a hospital-based cohort of HIV-infected patients around Varanasi, India. BMC Infect Dis. 2006;6:39.
28. Amatya R, Shrestha R, Poudyal N, Bhandari S. Opportunistic intestinal parasites and CD4 count in HIV infected people. J Pathol Nepal. 2011;1:118-21.

29. Sapkota D, Ghimire P, Manandhar S. Enteric parasitosis in patients with human immunodeficiency virus (HIV) infection and acquired immunodeficiency syndrome (AIDS) in Nepal. J Nepal Health Res Counc. 2004;2(1). http://www.jnhrc.com.np/index.php/jnhrc/article/viewFile/66/63.

30. Teklemariam Z, Abate D, Mitiku H, Dessie Y. Prevalence of intestinal parasitic infection among HIV positive persons who are naive and on antiretroviral treatment in Hiwot Fana Specialized University Hospital, Eastern Ethiopia. ISRN AIDS. 2013;2013:324329.

31. Roberts T, Stark D, Harkness J, Ellis J. Update on the pathogenic potential and treatment options for Blastocystis sp. Gut Pathog. 2014;6:17.

32. Alemu A, Shiferaw Y, Getnet G, Yalew A, Addis Z. Opportunistic and other intestinal parasites among HIV/AIDS patients attending Gambi higher clinic in Bahir Dar city, North West Ethiopia. Asian Pac J Trop Med. 2011;4(8):661-5.

33. Paboriboune P, Phoumindr N, Borel E, Sourinphoumy K, Phaxayaseng S, Luangkhot $\mathrm{E}$, et al. Intestinal parasitic infections in HIV-infected patients, Lao People's Democratic Republic. PLoS One. 2014;9(3):e91452.

34. Gupta K, Bala M, Deb M, Muralidhar S, Sharma DK. Prevalence of intestinal parasitic infections in HIV-infected individuals and their relationship with immune status. Indian J Med Microbiol. 2013;31(2):161-5.

35. Blackman E, Binder S, Gaultier C, Benveniste R, Cecilio M. Cryptosporidiosis in HIV-infected patients: diagnostic sensitivity of stool examination, based on number of specimens submitted. Am J Gastroenterol. 1997;92(3):451-3.

36. Gupta S, Narang S, Nunavath V, Singh S. Chronic diarrhoea in HIV patients: prevalence of coccidian parasites. Indian J Med Microbiol. 2008;26(2):172-5.

37. Fekadu S, Taye K, Teshome W, Asnake S. Prevalence of parasitic infections in HIV-positive patients in southern Ethiopia: a cross-sectional study. J Infect Dev Ctries. 2013;7(11):868-72.

38. Kulkarni SV, Kairon R, Sane SS, Padmawar PS, Kale VA, Thakar MR, et al. Opportunistic parasitic infections in HIV/AIDS patients presenting with diarrhoea by the level of immunesuppression. Indian J Med Res. 2009;130(1):63-6.

39. Sher A, Coffman RL. Regulation of immunity to parasites by $T$ cells and $T$ cell-derived cytokines. Annu Rev Immunol. 1992;10:385-409.

40. Sayasone S, Utzinger J, Akkhavong K, Odermatt P. Multiparasitism and intensity of helminth infections in relation to symptoms and nutritional status among children: a cross-sectional study in southern Lao People's Democratic Republic. Acta Trop. 2015;141(Pt B):322-31.

41. Nkenfou CN, Nana CT, Payne VK. Intestinal parasitic infections in HIV infected and non-Infected patients in a low HIV prevalence region, WestCameroon. PLoS One. 2013;8(2):e57914.

42. Cox FE. Concomitant infections, parasites and immune responses. Parasitology. 2001;122(Suppl):S23-38.

43. Ellis MK, Raso G, Li YS, Rong Z, Chen HG, McManus DP. Familial aggregation of human susceptibility to co- and multiple helminth infections in a population from the Poyang Lake region, China. Int J Parasitol. 2007;37(10):1153-61.

\section{Submit your next manuscript to BioMed Central and we will help you at every step:}

- We accept pre-submission inquiries

- Our selector tool helps you to find the most relevant journal

- We provide round the clock customer support

- Convenient online submission

- Thorough peer review

- Inclusion in PubMed and all major indexing services

- Maximum visibility for your research

Submit your manuscript at www.biomedcentral.com/submit

C BioMed Central 